\title{
Megaselia scalaris, an Ultimate Scavenger for Barely Degradable Solid Waste
} \author{
Goutham Reddy ${ }^{5}$ \\ ${ }^{1}$ Scientific Officer, Ramky Enviro Engineers Ltd., India \\ ${ }^{2}$ Department of Civil Engineering, Annamalai University, India \\ ${ }^{3}$ Head-Technical \& Planning and Research, Ramky Enviro Engineers Ltd., India \\ ${ }^{4}$ Department of Civil Engineering, Annamalai University, India \\ ${ }^{5} M D$ \& CEO, Ramky Enviro Engineers Ltd., India
}

Atun Roy Choudhury ${ }^{*}$, Ashok Kumar Natarajan ${ }^{2}$, Srinivas Kesavarapu ${ }^{3}$, Arutchelvan Veeraraghavan ${ }^{4}$ and

Submission: August 10, 2018; Published: August 27, 2018

*Corresponding author: Atun Roy Choudhury, Scientific Officer, Research and Development, Ramky Enviro Engineers Ltd., Hyderabad, India, Email: atnroy10@gmail.com

\begin{abstract}
The potential of the Megaselia scalaris as a readily available scavenger is underrated in all possible scenario. The capability of the laboratory flies in terms of discarding the hardly degradable matter yet to be explored and nurtured. Thus, the present study tried to emphasize the capability of the laboratory flies to minimize the scientific disposal issues associated with the barely degradable matter, often ranging approximately $7 \%$ in Indian municipal solid waste (MSW). Experiments were conducted in prototype bins using the thermopile variety of this mutant fly, which is predominant in the Indian subcontinent. The feeding process yielded an optimal weight reduction of $35 \%$ over the period of 11 days subjected to the environmental conditions. Moreover, the greater consumption rates, compatibility of the coffin fly larvae with the MSW ambiance and ability to develop symbiotism with other larval varieties established it as one of the most pertinent species for heavy fraction stabilization of MSW.
\end{abstract}

Keywords: Megaselia scalaris; Compost; Hardly-degradable; Macrobial digestion; RDF

\section{Introduction}

During the past decade, rapid urbanization and globalization of the Indian economy directly influenced the quantity generation of the solid waste [1,2]. In present era, multiple studies indicated that the production and characteristics of the solid waste often get attributed to household income [3]. Ultimately the safe disposal of the grudgingly degradable fraction of MSW arises an unresolved issue which further interferes with the environmental safety and human health [4-7]. Thus, a wholesome treatment system to sustainably address this underrated fraction of the MSW is of the utmost need to save the space constraint associated with landfilling. Unlike the western nations the scope of utilizing the above-delineated fraction as alternative fuel is considerably scanty due to the higher moisture content of the Indian MSW [8-10] and hence, the usage of coffin fly and its larvae for the ultimate disposal of the same found to be a pertinent option [11].

The Megaselia scalaris, an especial tropical fly belongs to Dipteran order and Phoridae family often due to its bizarre appearance named as the humpbacked fly or coffin fly due to its strange capability of digging deep beneath the soil cover and infesting on the corpse [12]. Multiple researches haave been already explored its potential risk associated with the emigration of this human pathogen and germination of myiasis into vertebrates [13-16]. Whereas, the potential applicability of this digestion giants has not been considered in any preceding research. An experimental work carried out by AlcaineColet et al. [17] claimed the feasibility of laboratory flies toward the successful degradation of some specific synthetic and industrial wastes $[18,19]$. Although, the impact of the surrounding environment over the feeding and mortality have not been discussed profoundly in the study. With respect to the researchers conducted so far laboratory flies reported to have a wide range of fodder compatibility ranging from biodegradable materials to industrial effluents such as paints and boot polishes $[18,19]$, though, the Alcaine-Colet et al. [17] stated the claims to be overstated and often such conditions lead to higher mortality rates in larval and pre-pupal stage. Therefore, the present study restricted the introduction of the persistent pollutants and potentially hazardous materials as a substrate and utmost attention was paid towards the maintenance of an appropriate ambiance to minimize the change in behavioural characteristics.

The prime objective of this study was to determine the most favourable ambient conditions associated with an optimum feeding rate of the laboratory fly and also to establish it as a reliable conversion and stabilization agent for the barely degradable fraction of the MSW. 


\section{Materials and Methods}

A clear benefit was obtained due to the conduction of the analytical work in tropical conditions where the prevalence of the native species has been optimized for the research work. The acclimatization factor has been nullified, resulting in minimization of the treatment period. Several stages involved in the successful conduction of the batch study were delineated below.

\section{Medium preparation}

Unsegregated and raw heterogeneous MSW was collected from Jawahar Nagar dump site, Hyderabad and subsequently manual sorting were performed to separate the targeted fraction which comprises tree leaves, wooden pieces, garden twigs, and other inert materials subjected to non-biodegradability. The suitable amount of process leachate was mixed with the same consortium to maintain an appropriate moisture content for the newly served diet meant for saprophagous digestion.

\section{Portrayal of the bioreactor}

It was one of the most delicate issues to ensure maintaining a suitable ambiance for the coffin flies. A prototype reactor was fabricated, attributed with external heating and lighting system. Also, a thermometer was installed to monitor the pertinent temperature range. Two different trails were conducted to figure out the influence of light on the treatment efficiency and the schematic of the reactor has been enclosed in Figure 1.

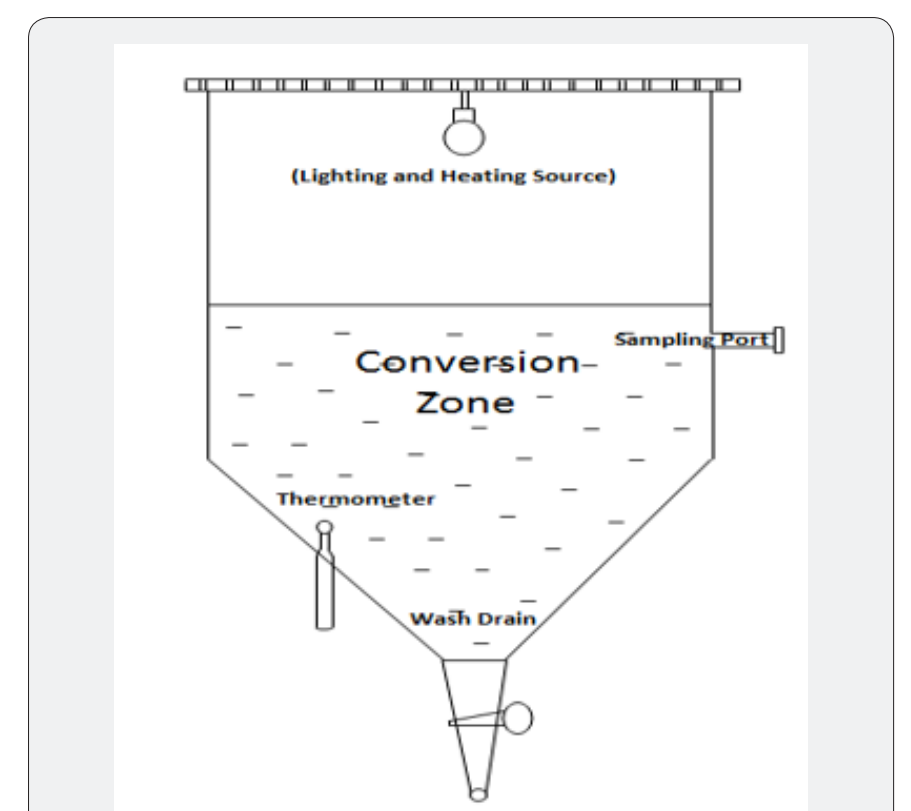

Figure 1: Bioreactor system.

\section{Ambient conditions}

The present treatment involves thermopiles and thus, an elevated ambient temperature was the requirement of the system and the same has been maintained using an external lighting and heating resource. Supply of oxygen also found to be playing a significant role towards the minimization of the maturation period. Other influencing environmental conditions include the availability of free space and turning frequency whereas, change in working pressure found to be ineffective in terms of treatment efficiency.

\section{Compost preparation}

The laboratory fly, Megaselia scalaris and house fly, Musca domestica yields a beneficial symbiotism with each other when given leniency to work together on a single substrate. The organic fraction of the MSW as a fodder for this symbiotic macro culture proven to be one of the best freely available nutrient resource which further produced high-quality compost as an end product.

\section{Refuse Derived Fuel (RDF) preparation}

RDF was the process yield of the solely conversion of segregated inert with the help of laboratory flies in absence of excess moisture. Primarily segregated field material was cured by exposing it to open sunbath over a period of $12 \mathrm{~h}$ and then the same was introduced to the treatment system. Once the consumption rate found to be drastically decreasing then the flies were separated from the system.

\section{Results and Discussion}

The main aim of this study was to interpret the influence of different environmental conditions over the treatment efficiency of the laboratory fly and to explore its feasibility as a macro conversion agent for barely degradable MSW fraction. The outputs of the extensive research work are represented as follows.

\section{Investigation on pertinent environment}

\section{Temperature vs. Treatment efficiency}

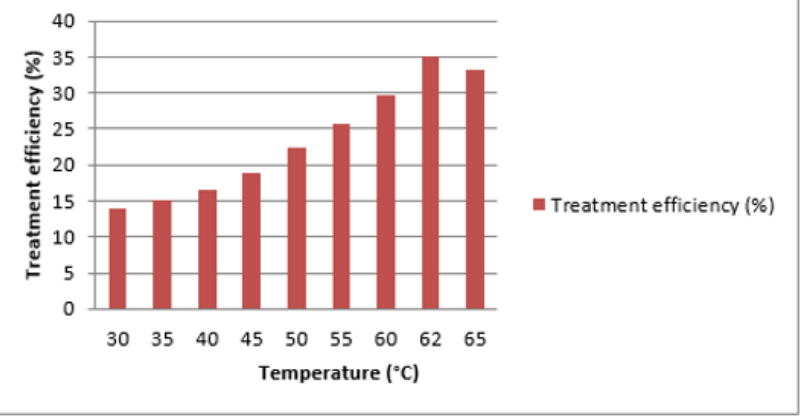

Figure 2: Variation in treatment efficiency with respect to temperature.

Involvement of thermopiles in the experiment confirms the obvious supply of external heating system which has been compensated by a $60 \mathrm{~W}$ electronic bulb. It worked as a dual source of light and heating at the same time and the temperature in the heap often found to reach a threshold value of $62{ }^{\circ} \mathrm{C}$ [20]. Two major parameters of interest namely, treatment efficiency and temperature portrayed a proportional relationship within a temperature range of $30{ }^{\circ} \mathrm{C}$ to $65{ }^{\circ} \mathrm{C}$ though, any further 
increment in temperature recorded as the reason of higher mortality rate [21]. Figure 2 tried to represent the correlation between the temperature and the conversion efficacy.

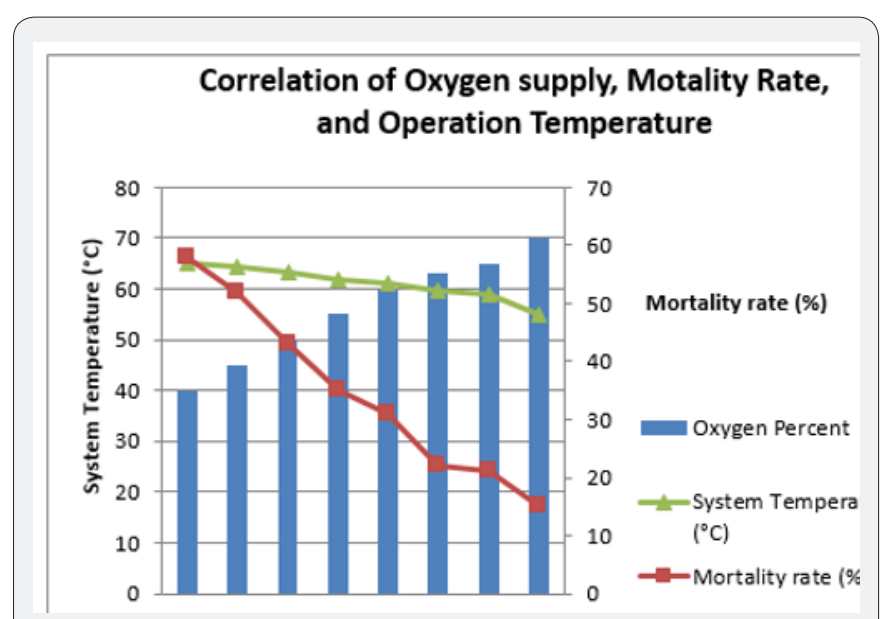

Figure 3: Impact of oxygen supply over temperature and mortality rate.

Ancillary, optimization of the oxygen supply was the utmost substantial issue due to the dual influence of oxygen over the conversion agent. Based on both detrimental and beneficial effects influenced by the oxygen levels an optimal supply of $63 \%$ was designed [20]. Any excess supply resulted in a reduction of the system temperature and contradictorily any decrement in oxygen level caused higher mortality rates. Thus, a partial facultative ambiance was maintained to ensure highest process yield. The graphical representation of the oxygen impact has been portrayed in Figure 3.

\section{Grub compost}

Compost was the yield of the symbiotic action performed by the mixed macro culture, incorporates laboratory fly and house fly. The biodegradable fraction was the MSW was introduced into an upper mesosphelic system with a temperature range controlled between $40{ }^{\circ} \mathrm{C}$ to $45{ }^{\circ} \mathrm{C}[22]$. Based on the result obtained from maturity test a relatively higher mean treatment period of 30 to 35 days was observed to retrieve field quality compost $[23,24]$. Once the maturation period is obtained both the adult flies as well as the larvae were compressed and homogenized into the medium which raised the organic nitrogen. The analysis report for the same has been enclosed in Table 1.

Table 1: Characteristics of the grub compost.

\begin{tabular}{|c|c|c|c|c|}
\hline Sl. No. & Parameters & Units & $\begin{array}{c}\text { Compost } \\
\text { Test } \\
\text { Values }\end{array}$ & FCo Standards* \\
\hline 1 & Particle size & $\%$ & 91.45 & $\begin{array}{c}\text { Minimum } 90 \% \\
\text { material should } \\
\text { pass through } \\
4.00 \mathrm{~mm} \text { sieve }\end{array}$ \\
\hline 2 & C:N Ratio & - & 12.53 & $20.0 \mathrm{Max}$ \\
\hline 3 & Bulk Density & $\mathrm{gm} / \mathrm{cm}^{3}$ & 0.92 & $<1.0$ \\
\hline 4 & Moisture & $\%$ & 20.57 & $15.0-25.0$ \\
\hline
\end{tabular}

\begin{tabular}{|c|c|c|c|c|}
\hline 5 & $\begin{array}{c}\text { Total } \\
\text { Organic } \\
\text { Carbon }\end{array}$ & $\%$ & 12.15 & $12.0 \mathrm{~min}$ \\
\hline 6 & $\begin{array}{c}\text { Total } \\
\text { Nitrogen } \\
\text { as N }\end{array}$ & $\%$ & 1.42 & $0.8 \mathrm{~min}$ \\
\hline 7 & $\begin{array}{c}\text { Total } \\
\text { Phosphate } \\
\text { as P205 }\end{array}$ & $\%$ & 0.36 & $0.4 \mathrm{~min}$ \\
\hline 8 & $\begin{array}{c}\text { Total Potash } \\
\text { as K20 }\end{array}$ & $\%$ & 0.33 & $0.4 \mathrm{~min}$ \\
\hline 9 & Pathogen & - & Nil & Absent \\
\hline
\end{tabular}

${ }^{*}$ Fertilizer Control Order

\section{Refuse derived fuel}

It's an alternate source of fuel produced from MSW which often used in power sector and cement industries [25,26]. The RDF products directly obtained from the pre-sorting of the MSW often anticipated with a calorific value of approximately $3200 \mathrm{cal} / \mathrm{g}$ [27]. But, due to the consumption of the lignin fraction by the laboratory flies, the RDF samples obtained were much better in quality and yielded grade of RDF. The detailed characterization report for the same has been tabulated in Table 2.

Table 2: Characteristics of the RDF.

\begin{tabular}{|c|c|c|c|c|}
\hline Sl No. & Parameter & Unit & Result & Remark \\
\hline 1 & $\begin{array}{c}\text { Moisture } \\
\text { Content @ } \\
105^{\circ} \mathrm{C}\end{array}$ & $\%$ & 14.2 & $\begin{array}{c}\text { Within Prescribed } \\
\text { Limit (ASTM }{ }^{*}\end{array}$ \\
\hline 2 & $\begin{array}{c}\text { Ash Content } \\
@ ~ 850{ }^{\circ} \mathrm{C}\end{array}$ & $\%$ & 11.7 & $\begin{array}{c}\text { Within Prescribed } \\
\text { Limit (ASTM) }\end{array}$ \\
\hline 3 & $\begin{array}{c}\text { Volatile } \\
\text { matter @ } \\
550^{\circ} \mathrm{C}\end{array}$ & $\%$ & 55.2 & $\begin{array}{c}\text { Within Prescribed } \\
\text { Limit (ASTM) }\end{array}$ \\
\hline 5 & $\begin{array}{c}\text { Net Calorific } \\
\text { Value }\end{array}$ & $\mathrm{cal} / \mathrm{g}$ & 4465 & $\begin{array}{c}\text { Within Prescribed } \\
\text { Limit (ASTM) }\end{array}$ \\
\hline $\begin{array}{c}\text { Gross } \\
\text { Calorific } \\
\text { value }\end{array}$ & $\mathrm{cal} / \mathrm{g}$ & 4344 & $\begin{array}{c}\text { Within Prescribed } \\
\text { Limit (ASTM) }\end{array}$ \\
\hline
\end{tabular}

*American Society for Testing and Materials

\section{Conclusion}

Application of laboratory flies in paramedical engineering is an established fact though the availability of the information is significantly scanty when it comes to the waste management scenario. The present work successfully emphasized the applicability of the Megaselia scalaris in reduction and valorisation of the barely degradable fraction of MSW associated with optimal environmental conditions. Thus, based on the above piece of evidence laboratory fly can be explicitly termed as the natural scavenger of the eco-system.

\section{Acknowledgments}

Authors would like to extend wholehearted thanks to Ramky Enviro Engineers Ltd. for financially assisting the research 
work (Grant Ref. No. U74140TG1994PLC0) and also Hyderabad Integrated Municipal Solid Waste Ltd. (HiMSW Ltd.) for extending laboratory facilities to carry out the experimental work

\section{References}

1. Jain M, Jain P, Jain V, Pandey A (2007) Physical and quantitative study of hospital solid waste and suggested management strategy at Bhopal city. Current World Enviroment 2(2): 225-228.

2. Narkhede SD, Pawar VD, Patil NJ, Attarde SB, (2009) Effectiveness of sewage sludge in composting process of municipal solid waste. Current World Environment 4(1): 171-174.

3. Samah MAA, Manaf LA, Aris AZ, Nor W (2011) Solid Waste Management: Analytical Hierarchy Process (AHP) application of Selecting Treatment Technology in Sepang Municipal Council, Malaysia. Current World Environment 6(1): 1-16.

4. Gautam A, Pathak G, Sahni A (2011) Assessment of Ground Water Quality at Municipal Solid Waste Dumping Site-Sewapura, Jaipur Current World Environment 6(2): 279-282.

5. Sakawi Z, Ismail L (2014) The Perception of the Langkawi Community on Solid Waste Management. Current World Environment 9(2): 237 243.

6. Naderi M, Baghon S, Amiri M, Rezazadeh M (2014) Greenhouse Gas Emissions (CO2-CH4) From Municipal Solid Waste Management Using Life Cycle Assessment (LCA) in Mahdsht City (IRAN). Current World Environment 9(2): 470-477.

7. Singh CHR, Dey M (2015) Role of NGO's in Solid Waste Management: A Study in Different Municipalities of Manipur, India. Current World Environment 10(1): 161-170.

8. Anis MD, Siddiqui TZ (2015) Waste to Energy: A Green Paradigm in Solid Waste Management. Current World Environment 10(3): 764-771.

9. Gandhe HD, Kumar A (2016) Efficient Resource Recovery Options from Municipal Solid Waste: Case Study of Patna, India. Current World Environment 11(1): 72-76.

10. Jahangeer, Gupta PK, Shaktibala, Rayani SA, (2016) Review and Concept Development for Electricity Generation from Municipal Solid Waste Using Mfcs. Current World Environment 11(2): 406-412.

11. Chakraborty A, Naskar A, Parui P, Banerjee D (2016) Developmental Variation of Indian Thermophilic Variety of Scuttle Fly Megaselia (Megaselia) scalaris (Loew, 1866) (Diptera: Phoridae) on Different Substrates. Scientifica 2016(4257081): 1-9.

12. Varney RL, Noor MAF (2010) The scuttle fly. Current Biology 20(11): R466.

13. Diclaro JW, Lehnert MS, Mitola MA, Pereira RM, Koehler PG (2011) A case study of Megaselia scalaris (Diptera: Phoridae) causing ocular myiasis in a western hognose snake. J Med Entomol 48(4): 934-936.
14. Disney RHL (2008) Natural History of the Scuttle Fly, Megaselia scalaris. Annu Rev Entomol 53: 39-60.

15. Mazayad SA, Rifaat MM (2005) Megaselia scalaris causing human intestinal myiasis in Egypt. Egypt Soc Parasitol 35(1): 331-340.

16. Sukontason KL, Boonsriwong W, Siriwattanarungsee S, Piangjai S, Sukontason K (2006) Morphology of puparia of Megaselia scalaris (Diptera: Phoridae), a fly species of medical and forensic importance. Parasitol Res 98(3): 268-272.

17. Alcaine-Colet A, Wotton KR, Jimenez-Guri E (2015) Rearing the scuttle fly Megaselia scalaris (Diptera: Phoridae) on industrial compounds: implications on size and lifespan. Peer] 3: e1085.

18. Lever JAW (1944) Maggots in imported boot polish. Agricultural Journal, Department of Agriculture, Fiji 15: 15.

19. McCrae AWR (1967) Infestation of emulsion paint by the fly Megaselia scalaris (Loew) (Dipt., Phoridae). Entomologist's Monthly Magazine 102: $241-243$.

20. Zuha RM, Razak TA, Ahmad NW, Omar B (2012) Interaction effects of temperature and food on the development of forensically important fly, Megaselia scalaris (Loew) (Diptera: Phoridae). Parasitol Res 111(5): 2179-2187.

21. Harrison DA, Cooper RL (2003) Characterization of development, behavior and neuromuscular physiology in the phorid fly, Megaselia scalaris. Comp Biochem Physiol A Mol Integr Physiol 136(2): 427-439.

22. Chakole PS, Jasutkar DB (2014) Comparative Study of Nirmalya Solid Waste Treatment by Vermicomposting and Artificial Aeration Composting. Current World Environment 9(2): 412-420.

23. Shah MC, Kansara JC, Shilpkar PG (2015) Composting of Calotropis gigantean Leaves in Presence of Sheep Dung. Current World Environment 10(1): 281-284.

24. Shah MC, Upadhyay DN, Shilpkar PG (2015) Composting of Calotropis gigantea Leaves using Mix Dung of Buffalo, Cow, Goat and Sheep. Current World Environment 10(3): 1044-1047.

25. Manninen H, Peltola K, Ruuskanen J (1997) Co-Combustion of RefuseDerived and Packaging-Derived Fuels (Rdf and Pdf) With Conventional Fuels. Waste Management and Research 15(2): 137-147.

26. Brás I, Silva ME, Lobo G, Cordeiro, A, Faria M, et al. (2017) Refuse Derived Fuel from Municipal Solid Waste rejected fractionsa Case Study. Energy Procedia 120: 349-356.

27. Grzesik K, Malinowski M (2016) Life cycle assessment of refusederived fuel production from mixed municipal waste. Energy Sources 38(21): 3150-3157. 
- Quality Editorial service

- Swift Peer Review

- Reprints availability

- E-prints Service

- Manuscript Podcast for convenient understanding

- Global attainment for your research

- Manuscript accessibility in different formats ( Pdf, E-pub, Full Text, Audio)

- Unceasing customer service

Track the below URL for one-step submission https://juniperpublishers.com/online-submission.php 